\title{
Alleviating Heat Stress during Summer Season on Performance of Growing Rabbits by Using Feed Withdrawal
}

\author{
M. F. A. Farghly ${ }^{1}$, A. E. Galal ${ }^{1}$ and H. Hamdon ${ }^{2}$ \\ ${ }^{1}$ Dept. of Poultry Production, Fac. of Agric., Univ. of Assiut, Assiut (71516), Egypt. \\ ${ }^{2}$ Dept. of Animal Production, Fac. Of Agric., Univ. of New Valley, Egypt \\ Corresponding Author:farghly20002000@yahoo.com\&farghly20002000@aun.edu.eg
}

\begin{abstract}
This study was designed to alleviate the heat stress during summer season on growth performance of New Zealand white rabbits by using feed withdrawal; Animals were reared in batteries and divided into four comparable groups (32 growing weaned rabbits in each). The four treatments were as follows: Control group (C) (rabbits were fed continuously for $24 \mathrm{hrs}$ ), T1 (feed was removed from 9 am to $12 \mathrm{am}$ ), T2 (feed was removed from 12.00 am to $3.00 \mathrm{pm}$ ) and T3 (feed was removed from 9.00 am to $3.00 \mathrm{pm}$ ). The results revealed that, daily body weight, feed conversion and some blood constitutes of growing NZW rabbits affected significantly. Feed withdrawal improved significantly body weight gain, feed conversion, dressed carcass and health status and decreased significantly whole fat percentage and rectal temperature. Rabbits of T2 and T3 groups showed the lowest $(\mathrm{P}<0.05)$ values of $\mathrm{A}: \mathrm{G}$ ratio and $\mathrm{N} / \mathrm{L}$ ratio when compared with their counterparts. Non-significant differences were found in the other morbidity and carcass characteristics due to feed withdrawal. From these results, it could be concluded, that feed withdrawal in growing rabbits during $12.00 \mathrm{am}$ to $3.00 \mathrm{pm}$ had beneficial impacts on performance and improved health status in the hot summer.
\end{abstract}

Key words: Feed withdrawal, growth performance, hot summer, rabbits.

\section{Introduction}

The most critical of all environmental factors that influence rabbit performance in open or semi-closed system conditions is ambient temperature (Farghly and Hamdon, 2015, 2016 and 2017ab; Farghly and ElHammady 2019). It is established that the rabbits during hot summer season are suffering to heat stress. The thermo-neutral zone for raising rabbits ranges between 15 and $25^{\circ} \mathrm{C}$, and $60-65 \%$ relative humidity (Marai et al., 2006). Exposure of rabbits to high ambient temperature $\left(30.0^{\circ} \mathrm{C}\right)$ may negatively affect the physiological status and then growth performance, which is the cornerstone of rabbit's farm (Marai et al., 2004; Farghly et al., 2016, 2017ab and 2019ab).

The harmful effects of high temperature during summer on rabbit performance at the economical and physiological levels are well documented. Feeding system is an important tool in the management practices, because it controls many physiological and behavioral processes. In the last decades, feed withdrawal was studied as a method to alleviate the deleterious effects of heat stress (Abdel-Monem et al., 2007; Farghly and Farghaly 2017 and Farghly et al., 2019a), to get the highest weights at marketing (Xiccato and Trocino, 2010 and Farghly and Hamdon 2017ab) and the best feed conversion or behavior (Sena et al., 2012; Farghly and Abdelnabi, 2014; Sena et al., 2015; Ojebiyi et al., 2015). Rabbits consume feed at any time in the day, though they prefer to feed nocturnally (Abd El-Monem et al., 2007 and Farghly and Abd El-Ati, 2011). Rabbits consume $60-70 \%$ of the feed at night, before dawn and after dusk (Gidenne et al., 2012 and Ojebiyi et al., 2015). Although, there are three top intervals of feed intake a day in the rabbits; these are during 3:00-06:00, 15:00-18:00 and 18:00-21:00 h (Ogbu et al., 2014; Farghly and Farghaly, 2017).

Many attempts have been done to overcome the adverse effects of heat stress by modifying environmental condition through nutritional, managerial, and physiological manipulation of rabbits (Selim et al., 2003; Farghly 2011\& Farghly et al., $2017 \mathrm{a} \& 2019)$. Therefore, the aim of this study was to detect the effect of different feed withdrawal system on growth performance, carcass characteristics, blood traits and some health aspects under summer conditions in Upper Egypt.

\section{Materials and Methods}

The present work was carried out at the Research Poultry Farm of Poultry Production Department, Faculty of Agriculture, Assiut University, Assiut, Egypt. The experiment was made during summer season, (2016-2017), where the environmental temperature ranged between $21.4{ }^{\circ} \mathrm{C}$ to $33.6{ }^{\circ} \mathrm{C}$ while, humidity was from 40.5 to $61.4 \%$. All rabbits were reared in single cages and divided to four groups ( 8 rabbit each). Animals were reared in batteries and divided into four comparable groups (32 growing weaned rabbits in each). The four treatments were as follows: Control group (C) (rabbits were fed continuously for $24 \mathrm{hrs}$ ), T1 (feed was removed from 9 am to $12 \mathrm{am}$ ), T2 (feed was removed from $12.00 \mathrm{am}$ to $3.00 \mathrm{pm}$ ) and $\mathrm{T} 3$ (feed was removed from $9.00 \mathrm{am}$ to $3.00 \mathrm{pm}$ ). The light intensity ranged from 10 to 20 Luxes, while feed and water were available all the time where rabbits received grower diet until 16 weeks of age. All growing rabbits were fed ad libitum on grower commercial diet containing $2670 \mathrm{ME} / \mathrm{kcal}$, $18.25 \% \mathrm{CP}$ and $11.17 \%$ CF according to NRC (1994). 
Body weight (BW) and feed consumption (FC) were estimated, where rabbits in each group were individually weighed weekly and FC was recorded weekly and calculated periodically every 4weeks. Feed conversion ratio (FCR) (g feed/ g gain) was calculated by dividing total feed consumed every 4 weeks $(\mathrm{g} / \mathrm{d} / \mathrm{h})$ in a pen by the total weight gain $(\mathrm{g} / \mathrm{d} / \mathrm{h})$ of its rabbits. At the end of the experiment (at 16 weeks of age), 3 rabbits per group were randomly chosen and slaughtered. Carcass weight was considered as the weight of fore part, intermediate part and hind part. The weight of additional edible parts included the weight of the liver, heart and kidneys. Dressed meat weight was obtained as the sum of the carcass weight and the weight of the edible parts. Dressing yield was calculated by dividing the dressed meat weight by preslaughter weight and expressed as a percentage. Rectal temperature $\left({ }^{\circ} \mathrm{C}\right)$ was measured by using a medical thermometer inserted into the rectum for 2 minutes at depth of 2 $\mathrm{cm}$.

At slaughter, 3 blood samples were taken in tubes contained EDTA. Plasma was separated by centrifugation at $3000 \mathrm{rpm}$ for 20 minutes and kept in a deep freezer at $-20 \mathrm{C}$ until the time of analysis. Plasma total protein, albumin, globulin, albumin: globulin ratio, total lipids, glucose, cortisol, AST and ALT were determined by enzymatic method using available commercial kits. Globulin was calculated by subtraction of Plasma albumin from total plasma protein. Morbidity corresponded to frequency of enteric disease or severe loss of weight. Health risk was the sum of morbidity and mortality.

Data collected were subjected to ANOVA by applying the General Linear Models Procedure of SAS software (SAS institute, 2009). Duncan (1955) was used to detect differences among means of different groups.

\section{Results and Discussion}

1. Growth performance: There were significant $(\mathrm{P}<0.05)$ differences in body weight $(12$ and 16 weeks of age), body weight gain (12-16 weeks of age) and feed conversion ratio (12-16 weeks of age) among all studied groups (Table, 1). The rabbits belonging to T2 group had the greatest averages and the best feed conversion ratio when compared with the other groups. In the present work, there are appropriate impacts on growth performance attributed to feed withdrawal. Moreover, rabbits avoid feeding during the hottest intervals of the day in the summer season and then there are not any over heat load, consequently rabbits avoid heat stress during these intervals.

These results were agreed with that reported by Meshreky et al., (2007), Farghly and Farghaly (2017), Farghly et al., (2017b) and Farghly (2019) who, found that body weights and daily weight gain were higher $(\mathrm{P}<0.01)$ in feed withdrawal groups. Also, they added that feed conversion ratio was better $(\mathrm{P}<0.01)$ by $13.14 \%$. Eiben et al.(2001) observed that feed timerestricted rabbits consumed 6 to $15 \%$ less feed than controls. Rommers, et al., (2004) reported that average body weight was heavier $(\mathrm{P}<0.01)$ in rabbits consumed more feed than does consumed low feed intake. Tůmová et al. (2003) indicated that feeding growing rabbits 7:00 $\mathrm{h}$ per day did not impact body weight at marketing age. Feeding time restriction to 7:00 h a day did not significantly affect growth performance of growing rabbits (Sena et al., 2012). Feed intake during rearing seems to be an important factor influencing body development.

Similar results reported by Mahrose (2000), Bovera et al. (2008), Ojebiyi et al. (2015), Farghly et al. (2017b), Farghly and El-Hammady (2019) and Farghly et al., (2019b) who observed that BW of rabbits on night feeding exceeded those of the midday feeding. However, Tůmová et al. (2003), Yakubu et al. (2007), Matics et al. (2012), Duperray et al. (2012) and Uhliřoval et al. (2015) observed non-significant changes in final body weight of growing rabbits due to feeding times. Farghly et al., (2019a) concluded that feed withdrawal and cold water in growing rabbits had beneficial impacts on their growth performance in the hot summer.

Feed withdrawal could be a suitable tool for improving feed conversion (Dalle-Zotte et al., 2005; de Oliveira et al., 2012; Matics et al., 2012; Uhliřoval et al., 2015). Bergaoui et al. (2008), Ogbu et al. (2014) and Sena et al., (2015) found that rabbits consume the most of their feed during afternoon intervals during summer season. Feeding activity during hottest intervals at morning "feeding rest ${ }^{\text {ee }}$ tends to shorten and reduction in stress (Ojebiyi et al., 2015). The reduction in growth is the main sign of heat exposure (Abdel-Monem et al., 2007), which may due to reduction in feed consumption, which stimulates peripheral thermal receptors to transmit suppressive nerve impulses to the appetite center in the hypothalamus resulting in a reduction in feed intake. Restricting feeding times enhancing feed utilization (Dalle- Zotte et al., 2005). However, Tumova et al., (2003) and Farghly and El-Hammady (2019) found that daily feed intake and feed efficiency did not significantly affected by feed withdrawal or restriction systems for rabbits. 
Table 1. Effect of feed withdrawal on growth performance of rabbits.

\begin{tabular}{|c|c|c|c|c|c|c|c|}
\hline \multirow{2}{*}{ Traits } & \multirow{2}{*}{$\begin{array}{l}\text { Age } \\
\text { (wks) }\end{array}$} & \multicolumn{4}{|c|}{ Treatments } & \multirow{2}{*}{ SEM } & \multirow{2}{*}{$P$ value } \\
\hline & & $\mathbf{C}$ & T1 & T2 & T3 & & \\
\hline \multirow{4}{*}{ Body weight (g) } & 4 & 533.88 & 542.72 & 523.12 & 515.64 & 3.92 & 0.7524 \\
\hline & 8 & 931.41 & 942.11 & 991.86 & 986.50 & 7.36 & 0.3287 \\
\hline & 12 & $1596.93^{\mathrm{b}}$ & $1690.35^{\mathrm{a}}$ & $1665.94^{\mathrm{ab}}$ & $1700.84^{\mathrm{a}}$ & 12.82 & 0.0469 \\
\hline & 16 & $2240.76^{c}$ & $2312.31^{\mathrm{bc}}$ & $2452.25^{\mathrm{a}}$ & $2400.22^{\mathrm{ab}}$ & 14.05 & 0.0004 \\
\hline \multirow{3}{*}{$\begin{array}{l}\text { Body weight } \\
\text { gain } \\
\text { (g/rabbit/day) }\end{array}$} & 4- 8 & 14.20 & 14.26 & 16.74 & 16.82 & 0.49 & 0.4835 \\
\hline & $8-12$ & 23.77 & 26.72 & 24.07 & 25.51 & 0.51 & 0.2947 \\
\hline & $12-16$ & $22.99^{\mathrm{c}}$ & $22.21^{\mathrm{c}}$ & $28.08^{\mathrm{a}}$ & $24.98^{\mathrm{b}}$ & 0.57 & 0.0007 \\
\hline \multirow{3}{*}{$\begin{array}{l}\text { Feed intake } \\
\text { (g/rabbit/day) }\end{array}$} & 4- 8 & 56.15 & 53.43 & 53.11 & 52.63 & 0.31 & 0.9672 \\
\hline & $8-12$ & 82.66 & 78.71 & 77.92 & 78.11 & 0.61 & 0.6271 \\
\hline & $12-16$ & 103.34 & 104.11 & 100.51 & 101.16 & 0.63 & 0.8567 \\
\hline Feed & 4- 8 & 3.95 & 3.75 & 3.17 & 3.13 & 0.12 & 0.6471 \\
\hline conversion & $8-12$ & 3.48 & 2.95 & 3.24 & 3.06 & 0.10 & 0.5274 \\
\hline (g feed/g gain) & $12-16$ & $4.49^{\mathrm{a}}$ & $4.69^{\mathrm{a}}$ & $3.58^{\mathrm{b}}$ & $4.05^{\mathrm{ab}}$ & 0.16 & 0.0325 \\
\hline
\end{tabular}

$\frac{1}{\mathrm{a}-\mathrm{d}}$ Means within each row for each division with no common superscripts are significantly different $(\mathrm{P} \leq 0.05)$.

\section{Carcass characteristics:}

No significant differences in the percentages of heart, kidney, fore part, intermediate part and hind part were found among all groups except liver, whole fat and dressed carcass percentages (Table, 2). The rabbits of $\mathrm{T} 2$ and $\mathrm{T} 3$ groups had significantly $(\mathrm{P} \leq 0.05)$ highest dressed carcass percentages as compared with the rabbits of $\mathrm{C}$ and $\mathrm{T} 1$ groups. The rabbits of $\mathrm{T} 1$ group had significantly $(\mathrm{P} \leq 0.05)$ highest liver percentages as compared with the rabbits of $\mathrm{T} 3$ group. While, The rabbits of $\mathrm{T} 3$ group had significantly $(\mathrm{P} \leq 0.05)$ lowest whole fat percentages as compared with the rabbits of $\mathrm{C}$ group. Carcass characteristics are the most important elements to take into consideration when assessing alternative feeding programs (Tůmová et al., 2006). The increase of marbling fat content could improve the eating quality of rabbit meat, which is low in fat and generally considered to be insufficiently tasty and juicy. This reduction in fat deposition in group 2 may be due to the decrease in feed consumption. In rabbit, fat content increases with age, provided that the age differences are not too small (Gondret et al., 1997).
Feed withdrawal could be a suitable tool for improving carcass characteristics and should be consider (reducing fat deposition) when estimating alternative feeding programs (Yakubu et al., 2007; de Oliveira et al., 2012 and Chodová et al., 2017). Contradictory findings in results of carcass characteristics could be caused by different intensities and times of feed restriction or changing. The current results are in line with those observed by Tůmová et al. (2003), Yakubu et al. (2007), Duperray et al. (2012), Ojebiyi et al. (2015) and Sena et al. (2015), Farghly and Farghaly (2017), Farghly et al., (2017b), Farghly (2019) who indicated non-significant differences in carcass characteristics due to feeding times. On the other hand, Matics et al. (2012) and Farghly and El-Hammady (2019) reported that rabbits fed ad libitum had significantly higher dressing percentage than those of the restricted groups. Farghly et al., (2019b) confirmed that no significant differences in percentages of heart, kidney, dissectible fat, Lean:bone ratio, moisture, ether extract were found among all groups (different feeding durations).

Table 2. Effect of feed withdrawal on carcass traits of rabbits.

\begin{tabular}{|c|c|c|c|c|c|c|}
\hline \multirow{2}{*}{ Traits } & \multicolumn{4}{|c|}{ Treatments } & \multirow{2}{*}{ SEM } & \multirow{2}{*}{$\begin{array}{c}P \\
\text { value }\end{array}$} \\
\hline & $\mathbf{C}$ & T1 & T2 & T3 & & \\
\hline Dressed carcass, \% & $58.51^{\mathrm{ab}}$ & $57.33^{b}$ & $59.66^{\mathrm{a}}$ & $59.50^{\mathrm{a}}$ & 0.33 & 0.0425 \\
\hline Heart, \% & 0.31 & 0.31 & 0.33 & 0.32 & 0.00 & 0.6487 \\
\hline Liver, \% & $2.84^{\mathrm{ab}}$ & $2.94^{\mathrm{a}}$ & $2.85^{\mathrm{ab}}$ & $2.60^{b}$ & 0.04 & 0.0426 \\
\hline Kidney, \% & 0.76 & 0.82 & 0.79 & 0.77 & 0.01 & 0.5351 \\
\hline Fore part, \% & 34.11 & 34.29 & 34.33 & 35.18 & 0.12 & 0.6457 \\
\hline Intermediate part, \% & 28.56 & 29.02 & 28.56 & 28.25 & 0.15 & 0.9364 \\
\hline Hind part, \% & 37.28 & 36.41 & 37.02 & 36.45 & 0.11 & 0.2726 \\
\hline Whole fat, \% & $3.18^{\mathrm{a}}$ & $3.06^{\mathrm{ab}}$ & $3.01^{\mathrm{ab}}$ & $2.52^{b}$ & 0.088 & 0.0330 \\
\hline
\end{tabular}

$\mathrm{a}$ and $\mathrm{b}$ Means within each row for each division with no common superscripts are significantly different $(\mathrm{P} \leq 0.05)$.

\section{Blood constituents:}

Data presented in Table (3), show insignificant differences $(\mathrm{P} \leq 0.05)$ in all blood constituents except $\mathrm{A}: \mathrm{G}$ ratio, N/L ratio and glucose values. Rabbits of $\mathrm{T} 2$ and $\mathrm{T} 3$ groups showed the lowest $(\mathrm{P}<0.05)$ values of
$A: G$ ratio and $N / L$ ratio when compared with their counterparts. Rabbits of T2 group showed the highest $(\mathrm{P}<0.05)$ values of glucose than those fed ad-libtum (C). Blood constituents in rabbits are as indicators of stress conditions and evaluation of the metabolic 
processes and the health status (Chodová et al., 2017). Plasma concentrations of total protein, globulin and albumin are related to its metabolism and were within the normal physiological range mentioned by Özkan et al., (2012). The present findings confirmed that restricting and feeding withdrawal did not impact the synthesis and transfer of plasma proteins and protein catabolism (Chodová et al., 2017). Feeding withdrawal of the day influences certain the biochemical parameters (Chodová and Tůmová, 2013 and Chodová et al., 2017).

Abdel-Monem et al., (2007) found that total protein, albumin and globulin were insignificantly affected by each of environmental conditions, feeding times or their interaction. The present results disagree with those found by Mahrose (2000), Farghly and Farghaly (2017) and Farghly et al., (2019a) who found that rabbits of T3 group (feed withdrawal during 10.00 to $16.00 \mathrm{~h})$ showed the lowest $(\mathrm{P}<0.05)$ values of body temperature, albumin/ globulin ratio $(\mathrm{A} / \mathrm{G})$ and neutrophil/ lymphocytes (N/L) ratio when compared with their counterparts. In addition, heat stress increase heterophil/lymphocyte ratio (Farghly et al., 2019b).

Glucose concentrations significantly influenced by withdrawal and that was in line with the findings of Rommers et al. (2004), while it was on contrary to what is reported by Van Harten and Cardoso (2010) and El-Speiy et al. (2015). Most obtained results were not impacted by withdrawal which corresponds with Mahrose (2000), Abdel-Monem et al. (2007), Chodová et al. (2017). The present findings disagree with those showed by Mahrose (2000) and Farghly and Hamdon (2017a) who obtained significant differences in the present blood components due to season effects. Farghly et al., (2019b) and Farghly and El-Hammady (2019) confirmed that the values of ALT and glucose were significantly lower in T3 group (lighting time at 2000 to 1000 and feeding time at 1000 to 2000). While, no significant differences were existed in most blood traits and behavior traits.

Table 3. Effect of feed withdrawal on blood constituents of rabbits.

\begin{tabular}{|c|c|c|c|c|c|c|}
\hline \multirow{2}{*}{ Traits } & \multicolumn{4}{|c|}{ Treatments } & \multirow{2}{*}{ SEM } & \multirow{2}{*}{$\begin{array}{c}P \\
\text { value }\end{array}$} \\
\hline & $\mathbf{C}$ & T1 & T2 & T3 & & \\
\hline Total proteins (mg/dL) & 6.79 & 7.08 & 7.11 & 6.94 & 0.05 & 0.8052 \\
\hline Globulin (mg/dL) & 2.79 & 2.84 & 3.06 & 2.98 & 0.04 & 0.0935 \\
\hline Albumin (mg/dL) & 4.00 & 4.24 & 4.05 & 3.96 & 0.04 & 0.1624 \\
\hline A:G ratio & $1.43^{\mathrm{ab}}$ & $1.49^{\mathrm{a}}$ & $1.32^{b}$ & $1.33^{\mathrm{b}}$ & 0.03 & 0.0421 \\
\hline Total lipids (g/dL) & 3.05 & 3.01 & 2.91 & 2.87 & 0.04 & 0.2602 \\
\hline Glucose (mg/dL) & $13.91^{\mathrm{b}}$ & $15.94^{\mathrm{ab}}$ & $16.98^{\mathrm{a}}$ & $16.05^{\mathrm{ab}}$ & 0.40 & 0.0462 \\
\hline AST U/I & 32.83 & 32.00 & 30.52 & 30.02 & 0.38 & 0.4258 \\
\hline ALT U/I & 18.62 & 19.00 & 17.54 & 17.60 & 0.03 & 0.2518 \\
\hline N / L Ratio & $0.60^{\mathrm{a}}$ & $0.59^{\mathrm{a}}$ & $0.48^{b}$ & $0.54^{\mathrm{ab}}$ & 0.46 & 0.0326 \\
\hline Cortisol (ng/mL) & 12.82 & 11.96 & 10.88 & 11.23 & 0.76 & 0.8125 \\
\hline
\end{tabular}

$\overline{\mathrm{a} \text { and } \mathrm{b}}$ Means within each row for each division with no common superscripts are significantly different $(\mathrm{P} \leq 0.05)$.

4. Physiological and Health aspects: Effect of feed withdrawal on physiological and health aspects is presented in (Table, 4). Rectal temperature of rabbits of T3 (feed was removed from 9.00 am to $3.00 \mathrm{pm}$ ) had the lowest temperature as compared with the control group. There were slight differences in morbidity, mortality and health risk percentages. It was found that rabbits of T2 group had fewer deaths than other groups. This may be due to less immunity or increased physiological stress. During heat stress conditions, mortality rate $(\%)$ is the most obvious indicator (Bovera et al., 2008). Samia Meshreky et al., (2007) reported that mortality rate was lower $(\mathrm{P}<0.05)$ in feed restriction groups.

Feed withdrawal has positive influence on the health status of growing rabbits (Chodová and Tůmová, 2013). Our study of feed withdrawal improved the health aspects of rabbits under heat stress conditions compared to the ad libitum group. The improvement in body temperature of rabbits of T3 (feed was removed from 9.00 am to $3.00 \mathrm{pm}$ ) in the present study might be attributed to reduction the heat load by decreased physiological stress, less activity and sleep. The reduction in body temperature of rabbits of T3 may help in enhancing performance and health status of rabbits. Abdel-Monem et al. (2007) and Ojebiyi et al. (2015) showed that rectum temperature was insignificantly influenced by feeding times.

It is well known that as a result of high ambient temperature production suffers, while body temperature and respiration rate can be highly affected (Yassein et al., 2008). Farghly and Farghaly (2017) and Farghly et al., (2019a) found that rabbits of T3 group (feed withdrawal during 10.00 to $16.00 \mathrm{~h}$ and tap water temperature) showed the lowest $(\mathrm{P}<0.05)$ values of body temperature when compared with their counterparts, while there were nonsignificant differences in morbidity, mortality and health risk percentages. Farghly and El-Hammady (2019) confirmed that the values of rectal temperature were significantly lower in T3 group (lighting time at 
2000 to 1000 and feeding time at 1000 to 2000). Furthermore, healthy traits improved relatively in groups fed during afternoon. While, no significant differences were existed in most blood traits and behavior traits.

Feeding withdrawal of the day influences certain behaviors and the total activity in rabbits (Ogbu et al., 2014) and can be a prohibition against health disorders (Tůmová et al., 2006). However, Tůmová et al., (2003), Bergaoui et al., (2008), Matics et al., (2012) and Duperray et al., (2012) concluded that feed restriction did not significantly affected mortality and health status of the growing rabbits. Bovera et al., (2008) found that mortality rate (\%) was significantly higher for restricted group than the control one due to heat stress. Farghly and Hamdon (2017a) and Farghly et al., (2019b) confirmed that healthy disorders significantly $(\mathrm{P} \leq 0.05)$ increased in $\mathrm{G} 2$ ( $\mathrm{T} 1$, feeding duration $12 \mathrm{~h}$ /day) and control than that in Group 3 (T2, feeding duration $9 \mathrm{~h}$ /day).

Table 4. Effect of feed withdrawal on physiological and healthy aspects of rabbits.

\begin{tabular}{|c|c|c|c|c|c|c|}
\hline \multirow{2}{*}{ Traits } & \multicolumn{4}{|c|}{ Treatments } & \multirow{2}{*}{ SEM } & \multirow{2}{*}{$\begin{array}{c}P \\
\text { value }\end{array}$} \\
\hline & $\mathbf{C}$ & T1 & $\mathbf{T 2}$ & T3 & & \\
\hline Rectal temperature $\left(\mathrm{C}^{\circ}\right)$ & $40.26^{\mathrm{a}}$ & $40.00^{\mathrm{ab}}$ & $40.04^{\mathrm{ab}}$ & $39.50^{\mathrm{b}}$ & 0.08 & 0.0254 \\
\hline Morbidity, \% & 12.5 & 0.00 & 0.00 & 12.5 & --- & --- \\
\hline Mortality, \% & 0.00 & 12.5 & 0.00 & 0.00 & --- & --- \\
\hline Health risk, \% & 12.5 & 12.5 & 0.00 & 12.5 & --- & --- \\
\hline
\end{tabular}

a and $b$ Means within each row for each division with no common superscripts are significantly different $(\mathrm{P} \leq 0.05)$.

\section{Conclusively}

it could be concluded from the present results, that feed withdrawal in growing rabbits during 9.00 am to $3.00 \mathrm{pm}$ or 12.00 am to $3.00 \mathrm{pm}$ had beneficial impacts on performance in the hot summer and at the same time improved health status. Nevertheless, this system was associated with less fat deposition which matches with the consumer's desire and health. Finally, feed withdrawal in growing rabbits during $9.00 \mathrm{am}$ to $3.00 \mathrm{pm}$ or $12.00 \mathrm{am}$ to $3.00 \mathrm{pm}$ as recommended had beneficial impacts on their growth performance.

\section{References}

Abdel-Monem, U.M., B.A. Khalil, and Kh.M. Mahrose, (2007). Effects of feeding times on performance of New Zealand White rabbit does. The $5^{\text {th }}$ International Congress of Rabbit Production under hot climates. Hurghada, Egypt, December $4-7$.

Bergaoui, R., M. Kammoun, and K.Ouerdiane, (2008).Effects of feed restriction on the performance and carcass of growing rabbits. Proceedings of the $9^{\text {th }}$ World Rabbit Congress, June 10-13, Verona, Italy, pp. 547-550.

Bovera, F., C.Di Meo, S. Marono, N.Vella, and Nizza, A. (2008). Feed restriction during summer: effect on rabbit growth performance. $9^{\text {th }}$ World Rabbit Congress, June 10-13, 2008, Verona, Italy, pp: 567-571.

Chodová, D. and E.Tůmová, (2013).The effect of feed restriction on meat quality of broiler rabbits: A review. Scientia AgriculturaeBohemica, 44 (1): 55-62.

Chodová, D., E.Tůmová, H.Härtlová, A.Fučíková, Z. Volek, and J. Vlčková, (2017).Changes of haematological and biochemical indices with age in rabbits with ad libitum and limited feed intake. Acta Vet Brno, 86: 29-35.

Dalle-Zotte, A., H.Rémignon, and J.Ouhayoun (2005). Effect of feed rationing during postweaning growth on meat quality, muscle energy metabolism and fibre properties of Biceps femoris muscle in the rabbit. Meat Science, 70: 301-306.

de Oliveira, M.C., R.P. da Silva, L.S. Araújo, V.R. da Silva, E.A. Bento, and D.M. da Silva, (2012). Effect of feed restriction on performance of growing rabbits. Revista Brasileira de Zootecnia, 41: 1463-1467.

Duncan, D. B. (1955).Multiple ranges and multiple Ftests. Biometrics, 11, 1-42.

Duperray, J., J.M. Laurent, R.Adelis, F. Haberkorn and A.Guyonvarch (2012). Time feed restriction reduces digestive disorders without decreasing growth performances of growing rabbits in ERE conditions. Proceedings of the 10 ${ }^{\text {th }}$ World Rabbit Congress, September 3 - 6, Sharm El-Sheikh, Egypt, pp: $663-668$.

Eiben Cs., K. Kustos, A.Kenessey, Gy.Virag and Zs Szendro. (2001). Effect of different feed restrictions during rearing on reproduction performance in rabbit does . World Rabbit Sci., 9(1) 9-14

El-Speiy, M. E., K.I. Kamel, A. E. Tag El-Din, A. E. Abd El-Hamid, and El- A.M. Kamhawey (2015).Effect of feed restriction on productive performance, carcass yield, blood pictures and relative organ weights of growing rabbits. Egyptian Poultry Science Journal, 35 (II): 439454.

Farghly, M.F.A. (2011). Using light flashes programme as a tool to avoid the hot weather effect on growth performance of New Zealand 
white rabbits. Egypt. Poult. Sci. Vol (31) (II): (437-451).

Farghly, M.F.A. and M. N. Abd El-Ati (2011). Effect of light flashes on growth performance, carcass characteristics and chemical composition of meat in New Zealand white rabbits. Egyptian J. Anim. Prod. (2011) 48 (1):55-67.

Farghly M. F. A. and M. A. Abdelnabi, (2014). Effect of light flashes on reproductive performance of New Zealand white rabbits (Abstract). $7^{\text {th }}$ International Poultry Conference, 3 - 6 November 2014, Ain Soukhna, Red Sea, Egypt.

Farghly M. F. A. and H. Hamdon (2015). Evaluating intermittent flashed light as economical light source for raising New Zealand white rabbits. Egypt. J. of Rabbit Sci., 25: $21-38$.

Farghly M. F. A. and H. Hamdon (2016). Suitable housing type of growing New Zealand White rabbits under hot conditions of Upper Egypt. Egyptian Journal of Rabbit Science, 26(1): 21 38.

Farghly M. F. A., M. A. Abdelnabi and H. Hamdon (2016). Effect of intermittent light flashes on reproductive performance of New Zealand White rabbits. Third International Conference on Agricultural Biotechnology Applications, April 59, 2016, Moshtohor and Sharm El-Sheikh, Egypt.

Farghly M. F. A. and M.M. Farghaly (2017). Change feeding time to alleviate the deleterious effect of hot assiut summer on performance of New Zealand white rabbits. The $8^{\text {th }}$ International Rabbit production in hot climates Conference, 8 11 March 2017, Hurghada, Red Sea, Egypt.

Farghly M. F. A. and H. Hamdon (2017a). Applying Cold Water In Managing New Zealand Rabbits In Hot Climate. The $8^{\text {th }}$ International Rabbit production in hot climates Conference, 8- 11 March 2017, Hurghada, Red Sea, Egypt.

Farghly, M. F. A., and H. Hamdon (2017b). Growth performance and carcass traits of New Zealand rabbits as affected by feed color and odor. The 16th Scientific Conference of Animal Nutrition, 28 November to 1 December 2017, Luxor, Egypt (Abstract).

Farghly M. F. A., G. B. Mahmoud and Kh. M. Mahrose (2017a). Using Light: Dark Time And Period To Alleviate The Heat Stress On Growing New Zealand White Rabbits During Hot Weather. The $8^{\text {th }}$ International Rabbit production in hot climates Conference, 8 - 11 March 2017, Hurghada, Red Sea, Egypt.

Farghly, M. F. A., Kh. M. Mahrose and M. M. Farghaly (2017b). Changing feeding time to avoid the harmful effects of hot summer on performance of growing New Zealand white rabbits. Egyptian Journal of Rabbit Science, 27 (2): 447- 461.
Farghly M. F. A. (2019). Effect of lighting and feeding time on growth performance of New Zealand White rabbits. The $9^{\text {th }}$ International Rabbit production in hot climates Conference, 26 - 30 March 2019, Hurghada, Red Sea, Egypt.

Farghly M. F. A. and H.Y. El-Hammady (2019). Effect of feed frequencies on growth performance of New Zealand White rabbits. The $9^{\text {th }}$ International Rabbit production in hot climates Conference, 26 - 30 March 2019, Hurghada, Red Sea, Egypt.

Farghly M. F. A., M. A. Metwally and Enas A. M. Ahmad (2019a). Alleviating the harmful effects of heat stress on growing New Zealand White rabbits by feed withdrawal and cold water. The $9^{\text {th }}$ International Rabbit production in hot climates Conference, 26 - 30 March 2019, Hurghada, Red Sea, Egypt.

Farghly M. F. A., A. E. Galal and M. I. Tawfeek (2019b). Effect of feeding system on growing New Zealand White rabbits. The $9^{\text {th }}$ International Rabbit production in hot climates Conference, 26 - 30 March 2019, Hurghada, Red Sea, Egypt.

Gidenne, T., S. Combs, and L. Fortun-Lamothe, (2012). Feed intake limitation strategies for the growing rabbit: effect on feeding behaviour, welfare, performance, digestive physiology and health: a review. Animal, 6: 1407-1419.

Gondret, F., J.Mourot and M. Bonneau, (1997). Developmental changes in lipogenic enzymes in muscle compared to liver and extramuscular adipose tissues in the rabbit (Oryctolagus cunicuIus). Comparative Biochemistry and Physiology 117B; 259-265.

Mahrose, Kh.M. (2000). Environmental studies on growth and reproduction traits in rabbits. M.Sc. Thesis, Faculty of Agriculture, Zagazig University, Egypt.

Marai, I.F.M., A.A. Askar and L.B. Bahgat, (2006). Tolerance of New Zealand White and Californian doe rabbits at first parity to the sub-tropical environment of Egypt Livestock Science 104:165172.

Marai, I.F.M., A.A. Haeeb and A.E. Gad, (2004). Growth performance traits and the physiological background of young doe rabbits as affected by climatic conditions and lighting regime, under sub-tropical conditions of Egypt. Proceedings $-8^{\text {th }}$ World Rabbit Congress -September 7-10, 2004 Puebla, Mexico, pp; 288-297.

Matics, Zs., A. Dalle-Zotte, I. Radnai, M. Kovács, , Sz.Metzger, and Zs. Szendrō, (2012). Effect of restricted feeding after weaning on the productive and carcass traits of growing rabbits. Proceedings of The $10^{\text {th }}$ World Rabbit Congress, September 3 - 6, Sharm El- Sheikh, Egypt, pp: 741 -745 .

National Research Council (NRC), 1994. Nutrient Requirements of Poultry.9th rev. ed. National Academy Press, Washington, D.C. 
Ogbu, C.C., A.O. Ani, and P. Nwogwugwu, (2014). Growth performance, feed preference and circadian variation in behavioural traits of rabbits reared singly and in group. Journal of Animal Production Advances, 4: 488-500.

Ojebiyi, O.O.; Olarinde, O.J.; Adepoju, A.A.; Akinola, A.O. and Adetutu, O.I. (2015). Performance of rabbits on exclusive day and/ or night feeding regime in the derived Savannah zone of Nigeria. Online Journal of Animal and Feed Research, 5: 45-49.

Özkan, C., A. Kaya, and Y. Akgül, (2012).Normal values of haematological and some biochemical parameters in serum and urine of New Zealand White rabbits. World Rabbit Science, 20: 253-259.

Rommers JM., R. Meijerjof , J.P.T.M. Noordhuizen and B. Kemp (2004). The effect of level of feeding in early gestation on reproductive success in young rabbit does. Animal Reproduct. Sci., 81 (1-2): 151-158.

Samia Z. Meshreky, T. A. Shamma, N. F. Abd ElHakim and M. A. El-Aaik (2007). Growth performance, pubertal characteristics and reproductive efficiency in New Zealand white female rabbits as affected by feeding regimen and age at first insemination. The $5^{\text {th }}$ Inter. Con .on Rabbit Prod. in Hot Clim., Hurghada, Egypt,, 451 - 467.

SAS, Institute, (2009). SAS User's Guide Statistic Ver 9.2 Edition SAS Institute Inc., Cary, Nc.

Selim A.D., Z.M., Soliman and A.M.A. Abdelkhalek (2003). Effect of the interaction between drinking water temperature and some dietary feed additives on performance of heat stressed rabbits. Egyptian J. Nutrition and Feeds, 231-244.

Sena, L., S.Sena, and Y. Biçoku, (2012). Effect of reduction of feeding time on the performance of growing rabbits. $3^{\text {rd }}$ International Scientific Symposium "Agrosym Jahorina, 2012", Faculty of
Agriculture, University of East Sarajevo, Jahorina, November 15-17, pp: 504-508.

Sena, S.; Sena, L., N.Nikolova and Y.Biçoku, (2015). The effect of restricted feeding for an extended period of time on the carcass`s fattening parameters of rabbits. Macedonian Journal of Animal Science, 5: 19-23.

Tůmová, E., L. Zita, and L. Štolc, (2006). Carcass quality in restricted and ad libitum fed rabbits. Czech Journal of Animal Science, 51: 214-219.

Tůmová, E., V. Skřrivanová and M.Skřivan, (2003). Effect of restricted feeding time and quantitative restriction in growing rabbits. Archivfür Geflügelkunde, 67: 182-190.

Uhliřoval, L., Z.Volek, , M.Marounek, and E.Tůmová, (2015). Effect of feed restriction and different crude protein sources on the performance, health status and carcass traits of growing rabbits. World Rabbit Science, 23: 263272.

Van Harten, S. and L.A. Cardoso, (2010). Feed restriction and genetic selection on the expression and activity of metabolism regulatory enzymes in rabbits. Animal, 4: 1873-1883.

Xiccato, G. and A. Trocino, (2010). Feed and energy intake in rabbits and consequences on farm global efficiency. In: The $6^{\text {th }}$ International Conference on Rabbit Production in Hot Climates, pp. 503-520. February 1-4, Assuit, Egypt, pp: 1-18.

Yakubu, A., A.E.Salako, Ladokun, A.Q., M.M. Adua and T.U.K. Bature, (2007). Effects of feed restriction on performance, carcass yield, relative organ weights and some linear body measurements of weaner rabbits. Pakistan Journal of Nutrition, 6: 391-396.

Yassein S.A., K. Gh. M. Mahmoud, N., Maghraby and O.H.Ezzo, (2008). Hot climate effects and their amelioration on some productive and reproductive traits in rabbit does. World Rabbit Sci., 16:173 - 181 . 